Zavoda za znanstveni rad

HAZU Varaždin

SANJA CVETNIĆ

Primljeno: 22. 10. 2018.

Sveučilište u Zagrebu, Filozofski fakultet

Prihvaćeno: 28. 10. 2019.

scvetnic@ffzg.hr

DOI: $10.21857 / y d k x 2 c r v j 9$

\title{
PROBUDENA VARAŽDINSKA BAŠTINA (U PET EMBLEMA)
}

Dvije ustanove, dvadeset osam izlagača okupljenih oko petnaest tema posvetili su stručni rad i istraživačku pozornost baštini Varaždina na znanstvenostručnom skupu »Očuvana baština grada Varaždina«, slijedeći doslovce program baroknih filologa sažet u motto: „Vodim u starinu [i] otkrivam zamračeno. " [»Antiqua reduco. Obsucra revelo. «] $]^{1}$. Teme skupa obuhvaćaju istraživanje arheološke baštine, povijesne građevine, muzejske predmete iz Gradskoga muzeja Varaždin ili slike iz Galerije starih i novih majstora. Zajedničko vezivo i ovoga skupa i rada pojedinih istraživača je - da ponovno posegnem za starijom metaforikom -»bdijenje i čuvanje» ["vigilantia et custodia «] ${ }^{2}$ nad baštinom, srodno XV. emblemu Andree Alciata koji prikazuje hram s pjevcima i zvonima, spremnima oglasiti se na uzbunu u opasnosti te s lavovima kao čuvarima, dovoljno snažnima za borbu protiv uljeza i napasnika. I ne samo to, emblematski bestijarij u pridruženom epigramatskom tekstu veliča lava i zbog toga što čuva i u snu, jer spava otvorenih

1 Program je ispisan na naslovnom bakrorezu (tal. frontespizio) što su ga potpisali Abraham van Diepenbeeck kao crtač (lat. delineavit) i Theodor Jonas van Merlen kao bakrorezac (lat. sculpsit) na početku prvoga sveska Acta Sanctorum iz 1643. godine. Usp. [Jean BOLLAND,] ACTA SANCTORVM Quotquot toto orbe col[I]untur. Vel à Catholicis Scriptoribus celebrantur, Quæ ex Latinis \& Græcis, aliarumque gentium antiquis monumentis collegit, digessit; Notis illustravit JOANNES BOLLANDVS SOCIETATIS IESV THEOLOGVS, Seruatâ primigeniâ Scriptorum phrasi. OPERAM ET STVDIVM CONTVLIT GODEFRIDVS HENSCHENIVS EIVSDEM SOCIET. THEOLOGVS. Prodit nunc duobus Tomis IANVARIVS, In quo MCLXX. nominatorum Sanctorum, \& aliorum innumerabilium memoria, vel res gestæ illustrantur. Ceteri menses ex ordine subsequentur. ANTVERPI/E, APVD IOANNEM MEVRSIAM. ANNO M. DC. XLIII.

2 [Andrea ALCIATO,] ANDRE/E ALCATI EMBLEMATA CUM COMMENTARIIS CLAVDII MINOIS I.C. FRANCISCI SANCTI BROCENSIS \& Notis LAVRENTII PIGNORII PATAVINI. Patauij apud Petrum Paulum Tozzium, Sub Signo SS. Nominis IESV 1621., 85-90. 
očiju (lat. »custos oculis quia dormit apertis") $)^{3}$. Konzervatori i restauratori, arheolozi i muzeolozi, sve su to Alciatovi stražari čije bdijenje i čuvanje baštine ublažuje štetu koju proizvodi priroda (nepogode, ali i prirodno propadanje tvari kroz vrijeme, trošenje), a još češće društvo (na znatno maštovitije i nepredvidljivije načine). Čuvanje i zaštita doimaju se zadatcima koji prvenstveno zahtijevaju srčanost i snagu, ali najveći je napor u odlukama koje su sudbonosne za objekt zaštite, odlukama koje zahtijevaju znanje i odgovornost, a često se donose u okviru promjenjivih državnih politika i novčanih ograničenja. Osim toga, mijenjaju se načela i zaštitarske mode pa je potrebna mudrost jedne poslovično domišljate sove da se razabere pravi put među pitanjima o tome treba li čuvati spomenik ili kulturni krajolik, ili oba, i kako to ostvariti. U širokoj ponudi spomenutih emblematskih pouka nalazi se i jedna koju lavovi baštine dobro znaju: »Remedia in arduo, mala in prono esse ${ }^{4}$. Sažeta latinština upozorava kako je oporavak težak, a šteta se dogodi lako i brzo. Ikonografski je opisana kao alegorija u kojoj Ata, božica zablude brza i širi zlo, obmanu, propast i ludost, a za njom se sporo vuku Lite, božice molbe, čijoj su se zaštiti utjecali oni koje je Ata unesrećila. S obzirom da je Ata krilata, a Lite stare, hrome i slaboga vida, popravak dolazi tek nakon dugo vremena: "Nil nisi post longo tempore restituunt. ${ }^{5}$

Kada se od globalnih mudrosti svrnemo na lokalno i krenemo u vremensku šetnju Varaždinom mnogo je građevina zasjalo post longo tempore. Na preobrazbu grada smo se već toliko navikli da je potrebno uključiti vremeplov i vratiti se u dvadeseto stoljeće (uz pomoć Schneiderove fototeke ili starih razglednica, na primjer), a potogovo u razdoblje nakon Drugoga svjetskoga i prije Domovinskoga rata (što već bilježe crno-bijele fotografije konzervatorske fototeke) kako bismo se prisjetili loše zakrpanih rupa i jama na putu prema najvažnijim spomenicima, pročelja s kojih cigla namiguje ispod otoka otpale žbuke, valova koje je vlaga iz temelja risala po dnu zgrada, tužnih i oštećenih stucco-uresa u crkvama i palačama, koji su - istini za volju - bili više ruglo nego kinč. ${ }^{6}$ Krilata je Ata obmanula i prepustila grad snu u kojem ga je polako obavijala trava zaborava, a sto hromih, slabovidnih i starih Lita desetljećima su polako omogućavale da Varaždin umije svoje lice, da se probudi i oživi. Mnogo je toga bila posljedica siromaštva pa bi se promjena mogla pripisati samo obogaćenju zajednice i države u odnosu na starija razdoblja, ali to je tek dio istine. Za novo, umiveno lice Varaždina zaslužna

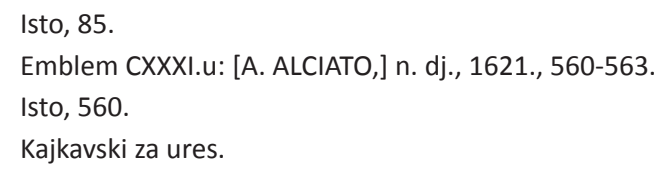


su i istraživanja, to jest znanstveni rad, potom stručna usavršavanja onih koji su zaduženi za baštinu pa i obljetnički skupovi i publikacije. Čini se da odlazak na sladoled varaždinske obitelji ili dogovor dviju prijateljica za kavicu uz scenografiju obnovljenih pročelja palača i zgrada na Korzu ili pak španciranje Varaždinaca i turista nema nikakve veze s akademskim svijetom; čini se da su arheolozi, konzervatori, muzealci, restauratori, arhitekti i druge struke odvojeni u vlastite salone kroz čije zatvorene prozore i guste zavjese ne dopire svakodnevni život, ali način na koji Varaždinci žive svoju povijesnu jezgru posljedica je savezništva različitih stručnjaka i znanstvenika koje je do toga dovelo, nepobjedive sloge, kako je Alciato nazvao tu vrlinu, "Concordia insuperabilis «. ${ }^{7}$ Već sljedeći emblem objašnjava kako se mogućnosti umnažaju s brojem sudionika tako da jedan ne može ništa, a dvojica mogu mnogo toga: "Vnum nihil, duos plurimum posse. ${ }^{8} \mathrm{Ta}$ se mudrost u odnosu Varaždina i njegove baštine potvrdila kroz mnoge primjere pa i kroz ovaj skup koji zajednički organiziraju Hrvatski restauratorski zavod u Zagrebu i Zavod za znanstveni rad Hrvatske akademije znanosti i umjetnosti u Varaždinu, duos plurimum posse.

Početak preobrazbe grada vezan je za nekoliko udaljenih događaja koji su ostavili blagotvorni trag, a plodovi su dolazili polako kao hrome Lite: godine 1925. na valu zanosa povodom tisućugodišnjice krunidbe Tomislava, to jest velike obljetnice hrvatskoga kraljevstva, hrvatska je kultura dobila zamašnjak. ${ }^{9}$ Povodom obljetnice (925 - 1925.) pokrenuta su istraživanja, osnovane udruge, a utemeljeno je i mnogo ustanova u Hrvatskoj, među kojima i Gradski muzej u Varaždinu. Današnji Trg kralja Tomislava, varaždinski Korzo, nakon brojnih preimenovanja u XX. stoljeću nosi upravo ime toga davnoga slavljenika. Vrenje vezano za hrvatsko proljeće osim političkih imalo je i znakove kulturnoga buđenja, a gradu je ostavilo zvuke Varaždinskih baroknih večeri (1968./1971.). ${ }^{10}$ Nakon velike obljetnice 800 godina od prvoga spomena Varaždina (1181. - 1981.), objavljen je opsežni Varaždinski zbornik 1181-1981 (1983.) na skoro 700 stranica, ${ }^{11}$ ali je i

Emblem XL. u: [A. ALCIATO,] n. dj., 213-215.

8 Emblem XL. u: [A. ALCIATO,] n. dj., 216-219.

9 Usp. Mario JAREB, Kralj Tomislav kroz tisuć godina: Kralj Tomislav između stvarnosti i mita te proslava tisućite obljetnice Hrvatskoga Kraljevstva 1925. godine i njezini odjeci do danas. Despot infinitus d. o. o., Hrvatski institut za povijest, Družba »Braća Hrvatskoga Zmaja«, Zagreb, 2017.

10 Usp. Ana KANIŠKI, »Uloga Varaždinskih baroknih večeri u promociji graditeljske i likovne baštine u Hrvatskoji šire te njezinoj obnovi« Hrvatska akademija znanosti i umjetnosti, Radovi Zavoda za znanstveni rad Varaždin, 27/2016., 235-266.

11 Usp. Varaždinski zbornik 1181-1981, Zbornik radova sa znanstvenog skupa održanog u Varaždinu od 1. do 3. listopada 1981. godine, Jugoslavenska akademija znanosti i umjetnosti, Skupština općine, gl. ur. Andre MOHOROVIČIĆ, Zagreb - Varaždin, 1983. 
utemeljen Zavod za znanstveni rad JAZU u Varažinu (1983.). Varaždinska baština uključena je sve češće u doktorska i projektna istraživanja povjesničara umjetnosti i arhitekata. ${ }^{12}$ Godine 2009. održan je skup povodom osamstote obljetnice kraljevskih posvlastica slobode grada, na kome je predstavljen već objavljeni zbornik, sada s više od 900 stranica. ${ }^{13}$ Potom su zaredali diplomski radovi, ${ }^{14}$ pa čak i doktorske disertacije posvećene samostalno temama varaždinske baštine. ${ }^{15}$ Usporedo s istraživanjima konzervatori, restauratori i muzealci trudili su se da grad svakim danom izgleda sve bolje, kako bi Alciato rekao: "In dies meliora«. ${ }^{16}$ Scenografija grada pogodnija za utvare, spodobe i smrtne sjenke ostala je u prošlosti, zamrznuta na starim snimkama. Njih sada pronalaze tek novinari i bloggeri pa ih objavljuju sučeljene podudarnim kadrom sadašnjega stanja, sve kako bi se oni, njihovi čitatelji i probuđeni Varaždin sa zadovoljstvom mogli ogledati u novome zercalu. U njemu se zrcale obnovljene palače, perivoji, umjetnine, povijesne rukotvorine i druge sačuvane i očuvane dragocjenosti koje tvore varaždinski thesaurus, a zbog kojih je Varaždin sām blago Hrvatske, Srednje Europe i - što je najvažnije - svojih građana.

12 Primjerice, doktorska disertacija Mirjane REPANIĆ BRAUN, Barokno slikarstvo u Hrvatskoj franjevačkoj provinciji sv. Ćirila i Metoda (Zagreb: Sveučilište u Zagrebu Filozofski fakultet, 1997.) obuhvatila je varaždinske slike i objavila ih u okviru istoimene knjige (Zagreb: Institut za povijest umjetnosti, Hrvatska franjevačka provincija sv. Ćirila i Metoda); akademik Mladen OBAD ŠćITAROCI organizirao je u Varaždinu međunarodni skup Dvorci i ljetnikovci - kulturno naslijeđe kao pokretač gospodarskog razvoja (13. i 14. listopada 2006.) i objavio istoimeni zbornik (suurednik Nikša BOžıć; Zagreb, Sveučilište u Zagrebu Arhitektnoski fakultet, 2006.).

13 Usp. 800 godina slobodnog i kraljevskog grada Varaždina 1209. - 2009., Zbornik radova s međunarodnog znanstvenog skupa održanog 3. i 4. prosinca 2009. godine u Varaždinu, Hrvatska akademija znanosti i umjetnosti Zavod za znanstveni rad Varaždin, Grad Varaždin, Varaždinska županija, gl. ur. Miroslav ŠıCEL, Slobodan KAŠTELA, Zagreb - Varaždin, 2009.

14 Primjerice, Ana KANIŠKI, Kapela sv. Josipa u franjevačkoj crkvi u Varaždinu: ikonografija i naručitelj. Zagreb, Sveučilište u Zagrebu Filozofski fakultet, 2011.; objavljen kao istoimeni članak u: Tkalčić: Godišnjak Društva za povjesnicu Zagrebačke nadbiskupije, Društvo za povjesnicu Zagrebačke nadbiskupije 16/2012., 303-412.

15 Usp. Petar PUHMAJER, Barokne palače u Varaždinu, Sveučilište u Zagrebu Filozofski fakultet, Zagreb, 2012.; Iva Potočnik, Sakralna umjetnička baština Varaždinskog arhiđakonata u kanonskim vizitacijama u 17. stoljeću, Sveučilište u Zadru, Poslijediplomski sveučilišni studij humanističkih znanosti, Zadar, 2016.

16 Emblem XLV. u: [A. ALCIATO,] n. dj., 1621., 232-234. 